\title{
Relationship between dust deposition rate and soil characteristics in an arid region of Iran
}

\author{
Bahareh AGHASI ${ }^{1 *}$, Ahmad JALALIAN ${ }^{1}$, Hossein KHADEMI $^{2}$ and Ali Asghar BESALATPOUR ${ }^{3}$ \\ ${ }^{1}$ Department of Soil Science, Isfahan (Khorasgan) Branch, Islamic Azad University, Isfahan, Iran \\ ${ }^{2}$ Department of Soil Science, College of Agriculture, Isfahan University of Technology, Isfahan 84156-83111, Iran \\ ${ }^{3}$ Inter $3 \mathrm{GmbH}$, Institute for Resources Management, Otto-Suhr-Allee 59, D-10585 Berlin, Germany \\ *Corresponding author: baharehaghasi@yahoo.com
}

Received: March 17, 2017; accepted: January 18, 2019

\begin{abstract}
RESUMEN
La formación de polvo es uno de los procesos que causan mayor impacto ambiental en zonas áridas y semiáridas. En este estudio se utilizó el algoritmo para la detección automática de interacción de chi-cuadrado (CHAID, por sus siglas en inglés) para determinar las relaciones no lineales entre las propiedades físicas y químicas del suelo y la tasa de sedimentación de polvo (TSP) tanto estacional como anual en la subcuenca del pantano de Gavkhouni, Irán central. Los resultados se compararon con los obtenidos por el método de regresión lineal múltiple (RLM). Ciento veinticuatro muestras de polvo atmosférico se tomaron estacionalmente en 31 emplazamientos. También se tomaron 96 muestras de suelo superficial. Se evaluaron tanto la tasa de sedimentación y la distribución del tamaño de partículas del polvo, como las propiedades físicas y químicas de las muestras de suelo. Los resultados mostraron que la TSP más alta y más baja corresponden al verano y al otoño, respectivamente. Con base en los resultados del algoritmo CHAID, las propiedades del suelo más importantes que afectaron la TSP en otoño, invierno, primavera y verano, así como la TSP anual, fueron el contenido de materia orgánica (coeficiente de importancia $[\mathrm{IC}]=0.34$ ), de yeso $(\mathrm{IC}=0.42)$, de arena $(\mathrm{IC}=0.39$ ), de limo $(\mathrm{IC}=0.31)$ y de arena $(\mathrm{IC}=0.23)$ del suelo, respectivamente. A partir de los resultados del algoritmo CHAID, parece que la distribución del tamaño de partículas del suelo, especialmente el contenido de arena, es un factor que afecta de forma determinante la TSP estacional y anual en el área de estudio. En este estudio, el modelo RLM mostró una exactitud no aceptable en comparación con el método no lineal del algoritmo CHAID. Por lo tanto, se puede concluir que en las áreas con alta complejidad ecológica y complejas relaciones no lineales entre los datos de entrada y salida, los métodos no lineales como el algoritmo CHAID son mejores que los métodos lineales como el RLM.
\end{abstract}

\begin{abstract}
Dust formation is one of the most seriously damaging environmental issues in arid and semiarid areas. In this study, the decision tree-based Chi-square Automatic Interaction Detector (CHAID) algorithm was used to determine the non-linear relationships of soil physical and chemical properties with seasonal and annual dust deposition rate (DDR) in Gavkhouni swamp sub-basin, Central Iran. The results were compared with those obtained by the multiple linear regression (MLR) method. A set of 124 atmospheric dust samples was seasonally taken from 31 sites. A set of 96 surface soil samples was also collected. DDR and dust particle size distribution, as well as the physical and chemical properties of soil samples were investigated. The results showed that the highest and lowest DDR belonged to summer and autumn, respectively. Based on the CHAID algorithm results, the most important soil properties affecting DDR in autumn, winter, spring and summer, as well as annual DDR were soil organic matter content (importance coefficient $[\mathrm{IC}]=0.34$ ), gypsum $(\mathrm{IC}=0.42$ ), sand $(\mathrm{IC}=0.39)$, silt $(\mathrm{IC}=0.31)$, and sand $(\mathrm{IC}=0.23)$, respectively. Based on the CHAID algorithm results, it appears that particle size distribution of surface soil, especially sand content is a determinant factor affecting seasonal and annual DDR in the study area. In this study, the MLR model had unacceptable accuracy
\end{abstract}


as compared with the non-linear CHAID algorithm method. Therefore, it seems that in areas with high ecological complexity and complex nonlinear relationships among input and output data, the nonlinear methods such as CHAID are superior to linear methods such as MLR.

Keywords: Dust deposition rate (DDR), CHAID, MLR, Gavkhouni swamp sub-basin.

\section{Introduction}

One of the most important phenomena in arid and semiarid climates is dust formation, which is among the seriously damaging environmental issues in these areas (Kutiel and Furman, 2003). In many environmental studies such as dust balance calculation in arid and semiarid areas (Rajot, 2001), water and soil pollutions caused by polluted sediments and toxic particles, and the amount of metal entering to the oceans (Jickells et al., 2005), the estimation or measurement of dust deposition rate (DDR) has been vital (Arimoto et al., 2005). DDR is influenced by many parameters including those affecting dust source, dust transfer, and particles deposition (McTainish et al., 1997). DDR essentially depends on dust supply rate from the source, precipitation, atmospheric turbulence and climatic conditions in the source and destination regions (Ta et al., 2004). Soil conditions such as soil moisture, soil texture, surface roughness, binding energy among soil particles, vegetation, and topography (Xuan et al., 2004) are mentioned as the main attributes of dust sources. Hojati et al. (2012) stated that climatic conditions in places where dust particles are deposited, distance from sources of dust, and differences between local and remote sources of dust storms are three factors controlling DDR. On the other hand, drought and increased desertification due to human activities can enhance DDR (McTainsh, 1999).

DDR in the world varies from 0.05 to $450 \mathrm{~g} \mathrm{~m}^{-2}$ year $^{-1}$ (Lawrence and Neff, 2009). Identifying dust sources and estimating dust emission rates are necessary, especially for investigating atmospheric dust pollutions (Lu et al., 2007). The extent of dust effects on air quality, public health and climate depends on the particle size and chemical composition of dust (Zheng et al., 2010). Generally, the chemical and mineralogical properties of dust particles are similar to those of the soil from which they are derived (Lawrence and Neff, 2009). Iran is not only one of the world's major sources of dust formation (Sing and
Sing, 2010), but also the geographical distribution of atmospheric dust shows that DDR in this country is very high (Tanaka and Chiba, 2006).

Various studies have been conducted on the physical and chemical properties, as well as the deposition rate of atmospheric dust in different regions of Iran (Zarasvandi et al., 2011; Hojati et al., 2012; Rashki et al., 2013; Norouzi et al., 2015; Naderizadeh et al., 2016). In recent years, the crisis caused by dust in Isfahan, a historical city in central Iran, has been claimed as one of the worst natural disasters affecting the daily life of citizens as well as the regional economy. The province of Isfahan is one of Iran's arid and semi-arid regions, having vast natural and anthropogenic sources for dust production. Currently, the main dust source in Isfahan city is the Segzi plain, located at the east. In addition, the Gavkhouni wetland with an area of 47000 ha in the southeast of Isfahan (52 $\left.39 \mathrm{E}, 3225^{\prime} \mathrm{N}\right)$, is one of the most valuable aquatic ecosystems of the region and plays a vital role for sustainable development. However, in recent years, the quality and quantity of this wetland's water have declined and destruction of this natural ecosystem has begun. Upstream diversions, as well as unfair management of water resources have led to reduced inflows downstream and undesirable ecological effects on the Gavkhouni wetland. On the other hand, excessive input of untreated industrial and domestic wastewater from Isfahan has influenced the quality of the wetland's water. Drought occurrences arising from climate change have intensified all of these problems in recent years. These conditions have had adverse impacts on the Gavkhouni wetland and have changed the hydrological regime of this natural ecosystem. Subsequently, it has turned into a saltpan.

Effects of the dried-up Gavkhouni wetland could be classified as ecological, social, economical and health-related issues. The main problem appears to be the salt desert with an area of 47000 ha that is covered with a thick salt deposit. When drought happens, wind carries the salts, chemicals, heavy metals, 
fertilizers and pesticides deposited in the wetland basin to other areas. These materials damage agricultural lands, pollute the ecosystem and cause a variety of diseases in affected rural and urban areas, especially Isfahan city.

Saline dust storms differ from ordinary storms in terms of suspended particle sources, chemical composition, particle size, and distribution processes. They are defined as a sort of environmental disaster in arid and semiarid areas that arises from dust extraction originated from mineral-rich sediments of the wetlands, and dried lakes and saline soils around the wetlands and lake margins (Abuduwaili et al., 2010). This kind of phenomenon has already been registered in many parts of the world such as the Aral Sea in Kazakhstan and Uzbekistan, the Balkhash Lake in Kazakhstan, Inner Mongolia in China, Southeast Australia and many other semi-arid and arid regions (Gill, 1996). It is obvious that due to the accumulation of salts, lack of vegetation and also wind erosion, these sediments will have a loose-structured surface (Abuduwaili et al., 2010). Compared to ordinary dust storms, saline dust storms carry high concentrations of fine particles of saline-alkaline salts such as sodium sulfate, sodium chloride and other potentially toxic substances that threaten the environment and human health in arid regions (Small et al., 2001; Mu et al., 2002).

The chemical composition of saline dust storms depends on soil properties, which might lead to doubling effects, depending on the nature of the carried materials. According to some studies, saline dust storms enriched by $\mathrm{CaCl}_{2}, \mathrm{NaCl}, \mathrm{MgCl}_{2}$ and other chloride particles can remain suspended in the atmosphere for a long time (Liu et al., 2011). Therefore, it is vital to study the atmospheric dust formation in the Gavkhouni sub-basin and determine the relationship between dust particles and their effective characteristics that can be considered as a possible natural source of dust production in Isfahan.

In recent decades, among the non-linear indirect methods, attention has been focused on intelligent systems in agriculture and natural resources studies (Twarakavi et al., 2009; Besalatpour et al., 2013; Abbaszadeh Afshar et al., 2016). Intelligent system methods such as decision tree based Chi-square $\mathrm{Au}$ tomatic Interaction Detection (CHAID) algorithm can be used to provide a low-cost solution and to solve the problems of imprecision and uncertainty, and also to avoid over-fitting problems (Huang et al., 2010; Besalatpour et al., 2014). These methods make intelligent systems able to analyze the longterm series of large-scale data and thus solve the problems that conventional methods are not still able to analyze and fix up in a cost-effective way (Wang et al., 2009; Huang et al., 2010; Besalatpour et al., 2013). The decision tree is a robust and popular data mining method and a tool for classification and prediction of problems, which is now widely used in medical, social, economic and environmental studies. The CHAID method is a decision tree algorithm that has been rarely used to investigate the determinant factors influencing DDR. In this study, the CHAID algorithm was used to determine the non-linear relationship of physical and chemical properties of soil in the Gavkhouni wetland sub-basin, located in Central Iran, and the seasonal and annual DDR. Furthermore, the results obtained with this method were compared to those of the commonly used multiple linear regression (MLR) in order to investigate the accuracy and performance of the CHAID algorithm.

\section{Materials and methods}

\subsection{Study area}

The Gavkhouni wetland sub-basin, located in Central $\operatorname{Iran}\left(31^{\circ} 51^{\prime}-32^{\circ} 45^{\prime} \mathrm{N}, 52^{\circ} 31^{\prime}-53^{\circ} 21^{\prime} \mathrm{E}\right)$, has an area of $3616 \mathrm{~km}^{2}$ (Fig. 1a). The average altitude of this sub-basin is $1549 \mathrm{~m}$. The international Gavkhouni wetland occupies about $472 \mathrm{~km}^{2}$ of the basin area and is located in the outermost part of the Zayandeh Roud river in the southeastern part of Isfahan city. Based on the Koppen classification, this region has a dry climate. Average annual precipitation is about $60 \mathrm{~mm}$ and the mean precipitation during the sampling period in autumn, winter, spring and summer was $18.2,31.8,9.1$, and $1.1 \mathrm{~mm}$, respectively. The average annual temperature is $18.6^{\circ} \mathrm{C}$ and the mean temperature during sampling periods in autumn, winter, spring and summer was 8.8, 8.9, 27.7, and $29.3{ }^{\circ} \mathrm{C}$, respectively. Figure 2 shows wind roses of the atmospheric dust sampling periods, which were plotted using the WR View 7.0.0 software.

\subsection{Sampling method}

A set of 124 atmospheric dust samples was collected from a flat surface with an area of $1 \mathrm{~m}^{2}$ (Fig. 3). This 
a)

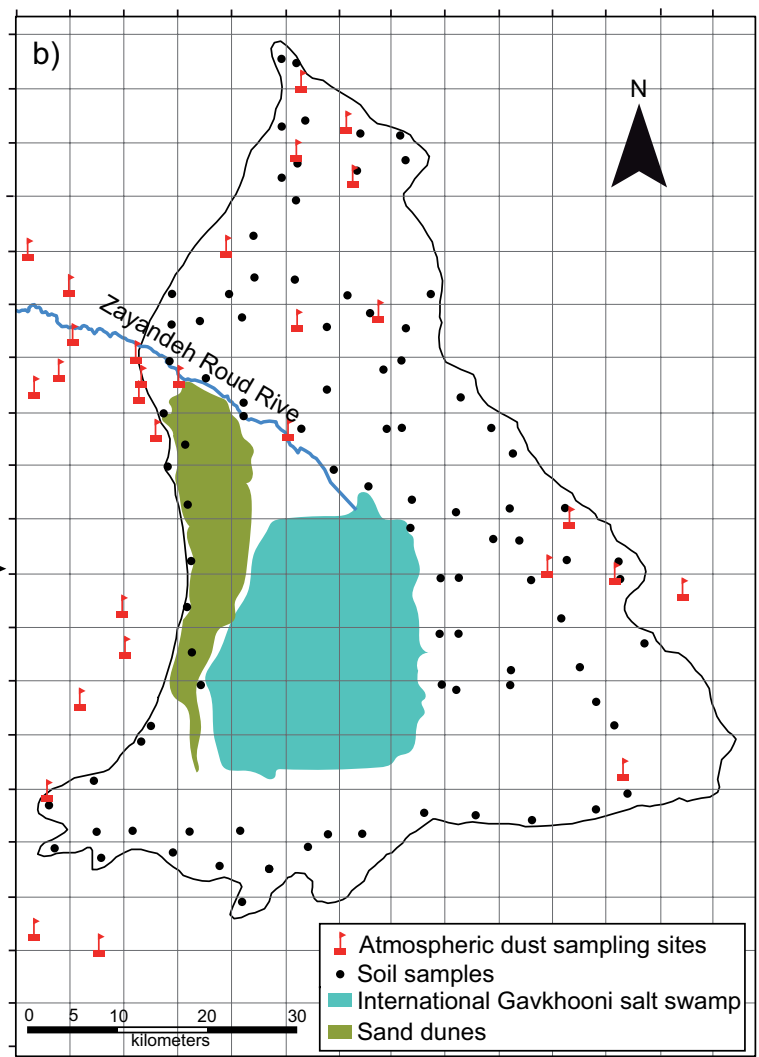

Fig. 1. The location of Gavkhouni wetland sub-basin. (a) Atmospheric dust and (b) surface soil sampling sites.

method has been widely used in previous studies (Menéndez et al., 2007; Hojati et al., 2012; Norouzi et et al., 2015). The sampling surface consisted of a glass plate $(1 \times 1 \mathrm{~m})$ covered with a PVC net $(2 \mathrm{~mm}$ mesh opening) in order to trap atmospheric dust particles. In each sampling site, a glass tray was placed on a roof of a one-floor building about 3-4 $\mathrm{m}$ above the ground level. Dust samples were collected from 31 sampling sites (Fig. 1b) from autumn 2013 to summer 2014. The last two months (60 days) of each four seasons were considered as a dust-sampling period.

Atmospheric dust samples trapped on glass trays were collected and transferred to the laboratory in plastic sealed containers. At the end of each sampling period, glass trays were washed with distilled water. DDR was calculated according to Eq. 1 (Hojati et al., 2012):

$$
D D R=\frac{\text { Mass of atmospheric dust }}{\text { Trap area } \times \text { Sampling period duration }}
$$

In addition, a particle size distribution analysis of atmospheric dust was carried out. Dust sand particles $(0.05-2 \mathrm{~mm})$ were separated by sieving through a 270-mesh US standard sieve. Dust silt particles (0.002-0.05 mm) were also separated from dust clay particles $(<0.002 \mathrm{~mm})$ by centrifuge, according to the Stokes law (Burt, 2004).

Surface soil samplings $(0-10 \mathrm{~cm})$ from the Gavkhouni sub-basin were carried out by the method of random sampling within blocks at the beginning of the atmospheric dust sampling, in autumn 2013. According to the Gavkhouni sub-basin area (i.e., $3616 \mathrm{~km}^{2}$ ), the region was divided into 96 blocks with an area of $6 \times 6 \mathrm{~km}$ and surface soil samples were collected randomly in each block from a depth of $0-10 \mathrm{~cm}$ (Fig. 1b). Soil samples were passed through a $2 \mathrm{~mm}$ sieve after air-drying. Gravel content was determined using the volumetric method. Other soil analyses included electrical conductivity (EC) and soil pH (Page et al., 1986), soil organic matter 


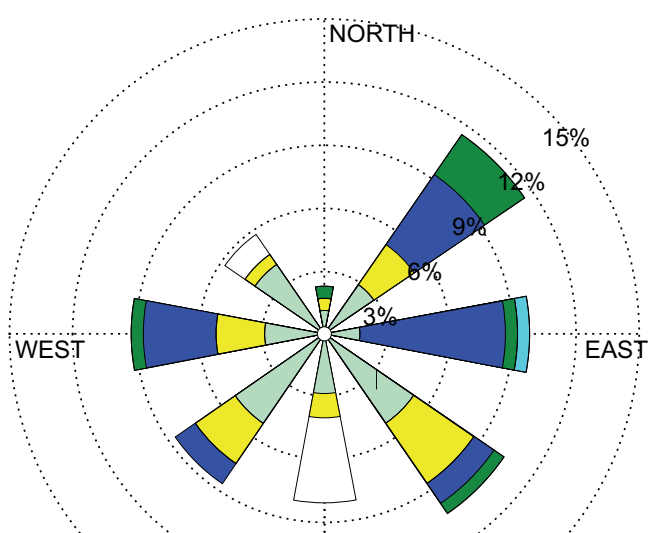

(a)

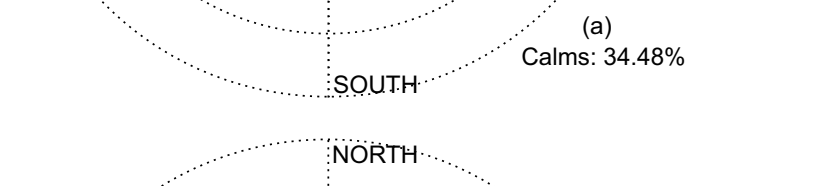

$25 \%$

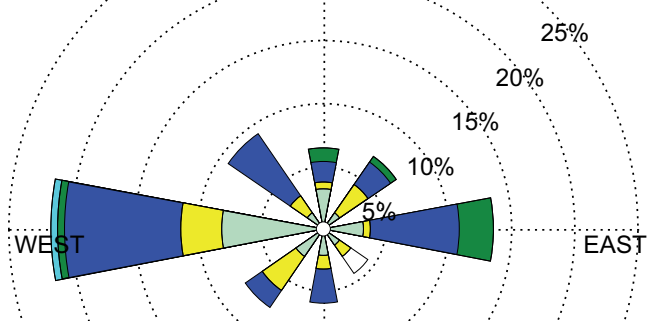

(c)

SOUTH Calms: $24.32 \%$

NORTH

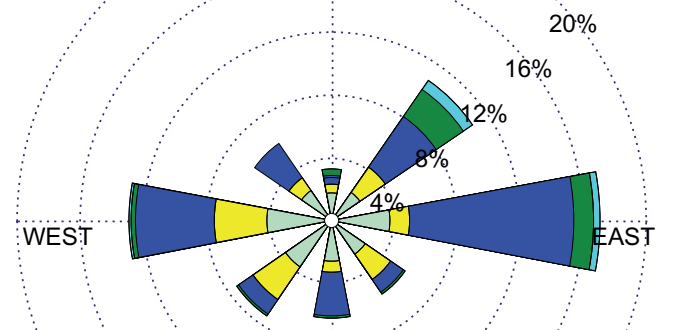

(e)

SOUTH
NORTH

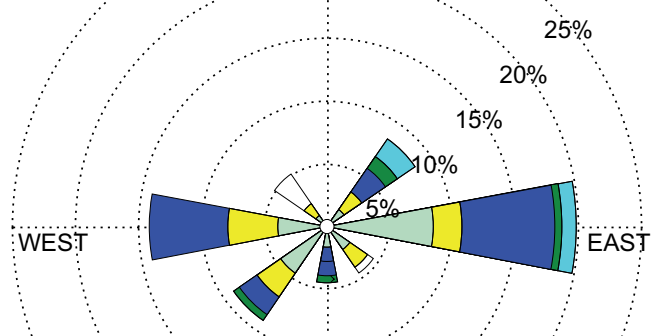

(b)

SOUTH Calms: $33.90 \%$

NORTH

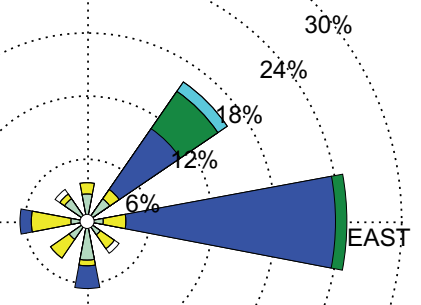

(d)

SOUTH

Calms: $30.65 \%$

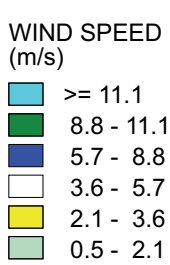

Fig. 2. Wind roses showing the direction and speed of wind during atmospheric dust sampling periods in (a) autumn, (b) winter, (c) spring, and (d) summer, as well as (e) annual in the study area. 


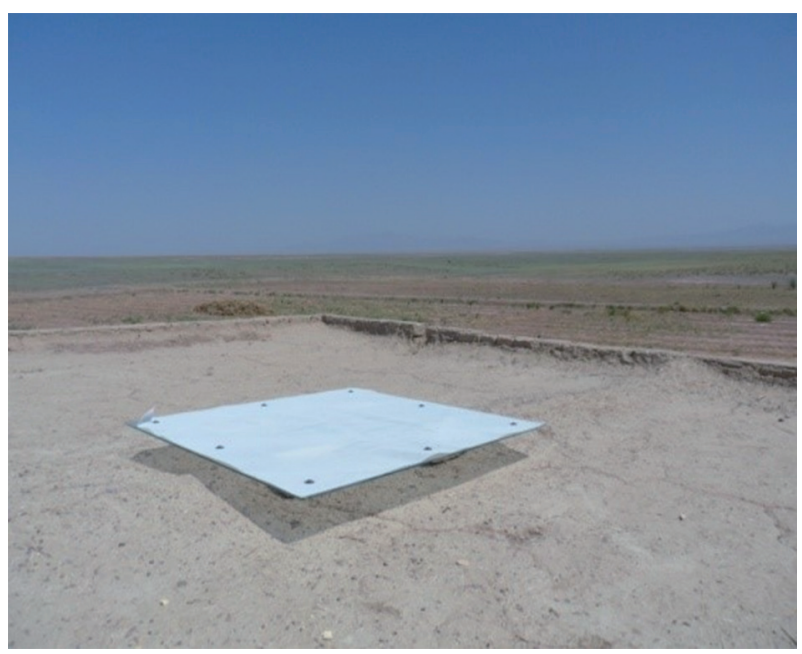

Fig. 3. Glass tray $(1 \times 1 \mathrm{~m})$ covered with a $2 \mathrm{~mm}$ PVC net mesh used for atmospheric dust collection.

(Walkley and Black, 1934), dissolved sodium concentration (Chapman, 1965), concentrations of dissolved calcium and magnesium (Burt, 2014), calcium carbonate equivalent (CCE) (Allison and Moodie 1965), gypsum (Artieda et al., 2006) and clay, silt and sand percentages (Gee and Bauder, 1986).

\subsection{Statistical descriptions}

SPSS 23 software was used to determine the statistical characteristics of data including maximum, minimum, mean, skewness, kurtosis and coefficient of variation $(\mathrm{CV})$, as well as investigating the correlation of DDR and soil properties. Distribution of variables was investigated using the Kolmogorov-Smirnov test (Massey, 1951).

\subsection{Multiple linear regression}

Linear regressions are simple modeling methods that can be used to predict one or more response variable (dependent) values from a set of predictors (independent). Linear regressions may be used for bivariate and/or multiple regressions. In bivariate regressions, there are one independent variable and one dependent variable, while in multiple regression analysis there are one dependent variable and two or more independent variables. Eq. (2) is an example of an overall multiple linear regression:

$$
Y=\beta_{0}+\beta_{1} X_{1}+\beta_{2} X_{2}+\beta_{3} X_{3}+\ldots+\beta_{n} X_{n}
$$

Where $Y$ is the dependent variable, $X$ is the independent variable, and $\beta_{\mathrm{i}}$ is the regression coefficient of variable $X_{\mathrm{i}}$ (Schneider et al., 2010).

\subsection{CHAID algorithm method}

The CHAID method was originally proposed by Kass (1980) and was then further developed by Magidson (1993). CHAID is considered one of the main decision-tree methods. In order to build a decision tree, this method splits the data into similar number of subsets until each subset of data covers a given number of samples. The CHAID algorithm can produce a decision tree that, in some cases, acts as non-binary. In fact, it uses multiple separate methods instead of binary separation means that can be divided into more than 90 parents. This algorithm uses the chi-square test to decide in each division for specifying child nodes. Tree branches are then pruned to fulfill the stop criteria or reach the required level of complexity.

In other words, the CHAID algorithm first finds the differences between each sample and the other samples to produce a tree. The pruning of the tree is done by finding the differences (Chattamvelli, 2011). In CHAID trees, the homogeneity of the groups that generated the tree is evaluated by a Bonferroni corrected P-value obtained from the chi-square statistic applied to two-way classification tables with $\mathrm{K}$ splits and $\mathrm{C}$ classes for each tree node (Maroco et al., 2011):

$X^{2}=\sum_{c=1}^{c} \sum_{k=1}^{k} \frac{\left(n_{c k}-\hat{n}_{c k}\right)^{2}}{\hat{n}_{c k}} \approx X^{2}(C-1)(K-1)$

where $\hat{n}_{c k}$ refers to the observed frequencies of the cell $c k$ and $\hat{n}_{c k}$ is an expected frequency under the null hypothesis of two-way homogeneity. In the CHAID analysis, the epsilon parameter for convergence and the maximum number of runs for convergence were set at 0.001 and 100, respectively. The Pearson method was used for the chi-square of the categorical target. The variable selection using CHAID was carried out using Clementine 15 software.

It should be noted that the temporal variability studies (both CHAID and MLR) were performed with the assumption that the physical and chemical characteristics of surface soil did not have a notable temporal variability in the area during the short study period, thus soil samples were collected only once. 


\section{Results and discussion}

\subsection{Statistical description of the studied properties} Table I shows annual and seasonal DDR statistics and also some measured physical and chemical parameters of surface soil in the study area. The maximum and minimum DDR were 4.8 and $3.0 \mathrm{t} \mathrm{km}^{-2}$ month $^{-1}$ corresponding to summer and autumn, respectively. Furthermore, the maximum and minimum coefficients of variation for DDR were found in summer and spring, respectively. Norouzi (2016) also studied DDR in Isfahan province and reported that summer and autumn had the highest and lowest DDR, respectively, in this region. Ta et al. (2004) studied DDR in Gansu province, China and found that the highest and lowest DDR may happen in spring and autumn. Javed et al. (2015) reported that concentrations of all size fractions were lowest during the monsoon sampling period at all sites in Faisalabad, Pakistan.

Al-Harbi (2015) investigated the monthly total amount of dust fall in Shuwaikh city, Kuwait and reported that the highest DDR in the study area was observed during the summer. It appears that dryness, and lack of moisture and rainfall in summer are the main reasons for increased DDR as well as a high coefficient of variation (CV) during this season.
The adhesion of dust particles is probably increased by the increase in rainfall and relative humidity, which leads to reduced dust generation in the source area and ultimately to reduced DDR in the deposition area. On the other hand, precipitation affects soil moisture and vegetation, which are the two most important factors controlling dust, and reduces the amount of dust produced (Ta et al., 2004). Kutiel and Furman (2003) reported that rainfall and the presence of vegetation significantly reduced the amount of dust because of their impacts on wind speed and particle sizes. Among the surface soil properties in the study area, gypsum, EC and sodium adsorption ratio (SAR) with a $\mathrm{CV}>100 \%$ (Nielsen and Wendroth, 2003) had a strong variation and $\mathrm{pH}$ with a $\mathrm{CV}<10 \%$ showed a weak variation. The reason for the observed changes in parameters of gypsum, EC and SAR might be the salty wetland in the region and large variations of soluble salts in soil from the wetland. The minimum $\mathrm{CV}$ value belonged to $\mathrm{pH}$, since $\mathrm{pH}$ is the logarithm of $\mathrm{H}^{+}$concentration in soil solution and if this parameter is reflected directly by proton concentration, it could show more changes. Other researchers have also observed less variation in soil $\mathrm{pH}$ than other soil parameters (Tesfahunegn et al., 2011; Mousavifard et al., 2013).

Table I. Descriptive statistics of physical and chemical properties of soil and DDR used for developing the CHAID model.

\begin{tabular}{|c|c|c|c|c|c|c|c|c|}
\hline Parameters & Unit & Min. & Max. & Mean & Skewness & Kurtosis & $\mathrm{K}-\mathrm{S}$ & $\mathrm{CV}(\%)$ \\
\hline $\mathrm{DDR}_{\text {Aut }}$ & $\mathrm{t} \mathrm{km}^{-2}$ month $^{-1}$ & 0.1 & 15.2 & 3.0 & 1.8 & 3.3 & 0.00 & 118.8 \\
\hline $\mathrm{DDR}_{\text {Win }}$ & $\mathrm{t} \mathrm{km}^{-2}$ month ${ }^{-1}$ & 0.1 & 18.1 & 3.9 & 1.9 & 2.8 & 0.00 & 118.5 \\
\hline $\mathrm{DDR}_{\mathrm{Spr}}$ & $\mathrm{t} \mathrm{km}^{-2}$ month ${ }^{-1}$ & 0.1 & 15.0 & 3.6 & 2.2 & 7.1 & $0.07^{*}$ & 80.8 \\
\hline $\mathrm{DDR}_{\text {Sum }}$ & $\mathrm{t} \mathrm{km}^{-2}$ month ${ }^{-1}$ & 0.3 & 27.4 & 4.8 & 2.7 & 7.9 & 0.00 & 133.1 \\
\hline $\mathrm{DDR}_{\text {Annual }}$ & $\mathrm{t} \mathrm{km}^{-2} \mathrm{yr}^{-1}$ & 6.9 & 221.5 & 46.1 & 2.9 & 6.4 & 0.00 & 98.6 \\
\hline Gravel $(2-20 \mathrm{~mm})$ & $\%$ & 0.0 & 25.8 & 12.9 & 0.1 & -1.0 & $0.18^{*}$ & 52.9 \\
\hline Sand $(0.05-2 \mathrm{~mm})$ & $\%$ & 61.2 & 86.7 & 76.6 & -0.7 & -0.4 & 0.02 & 8.6 \\
\hline Silt $(0.002-0.05 \mathrm{~mm})$ & $\%$ & 5.2 & 26.7 & 11.0 & 1.5 & 2.6 & 0.00 & 44.1 \\
\hline Clay $(<0.002 \mathrm{~mm})$ & $\%$ & 7.5 & 21.5 & 12.4 & 1.1 & 1.4 & 0.00 & 28.5 \\
\hline SOM & $\%$ & 0.0 & 1.6 & 0.4 & 2.4 & 7.4 & 0.00 & 81.9 \\
\hline CCE & $\%$ & 9.3 & 47.3 & 26.8 & 0.7 & 0.3 & 0.00 & 35.2 \\
\hline Gypsum & $\%$ & 0.0 & 50.4 & 3.7 & 5.0 & 26.6 & 0.00 & 243.9 \\
\hline $\mathrm{pH}$ & - & 6.8 & 8.7 & 7.9 & -0.5 & -0.6 & $0.13^{*}$ & 6.8 \\
\hline $\mathrm{EC}$ & $\mathrm{dS} \mathrm{m}{ }^{-1}$ & 0.9 & 361.7 & 60.9 & 2.0 & 3.3 & 0.00 & 159.2 \\
\hline SAR & $\left(m e q L^{-1}\right)^{1 / 2}$ & 1.4 & 898.7 & 151.6 & 1.7 & 3.4 & 0.00 & 141.8 \\
\hline
\end{tabular}

K-S: Kolmorov-Smirnov test; CV: coefficient of variation; DDR: dust deposition rate; SOM: soil organic matter; CCE: calcium carbonate equivalent; EC: electrical conductivity; SAR: sodium adsorption ratio.

*Significant at the $5 \%$ significance level. 
Table II. Correlation coefficients between physical and chemical properties of soil and DDR.

\begin{tabular}{lccccc}
\hline Parameters & DDR $_{\text {Aut }}$ & $\mathrm{DDR}_{\text {Win }}$ & $\mathrm{DDR}_{\text {Spr }}$ & $\mathrm{DDR}_{\text {Sum }}$ & $\mathrm{DDR}_{\text {Annual }}$ \\
\hline Gravel & -0.34 & -0.20 & $-0.40^{*}$ & -0.30 & -0.34 \\
Sand & 0.04 & -0.20 & -0.04 & 0.28 & 0.07 \\
Silt & -0.07 & 0.16 & -0.19 & $-0.37^{*}$ & -0.13 \\
Clay & 0.06 & 0.18 & 0.34 & -0.10 & 0.04 \\
SOM & 0.17 & 0.33 & 0.26 & -0.08 & 0.07 \\
CCE & 0.26 & $0.49^{* *}$ & 0.05 & -0.02 & 0.21 \\
Gypsum & 0.31 & 0.14 & 0.18 & 0.24 & 0.22 \\
pH & $-0.43^{*}$ & $-0.45^{*}$ & $-0.40^{*}$ & -0.27 & $-0.43^{*}$ \\
EC & 0.25 & $0.45^{*}$ & 0.28 & 0.05 & 0.22 \\
SAR & 0.20 & $0.44^{*}$ & 0.12 & 0.02 & 0.18 \\
\hline
\end{tabular}

DDR: dust deposition rate; SOM: soil organic matter; CCE: calcium carbonate equivalent; EC: electrical conductivity; SAR: sodium adsorption ratio.

${ }^{*}$ Significant at the $5 \%$ significance level; ${ }^{* *}$ significant at the $1 \%$ significance level.

To determine the relationship between annual and seasonal DDR and surface soil properties in the study area, correlation coefficients were calculated (Table II). The results showed that annual and seasonal DDR (except for summer) are negatively correlated with soil $\mathrm{pH}$. DDR in winter showed a significant positive correlation with CCE, EC, and SAR. However, no significant correlation was observed between the annual and seasonal DDR and other soil parameters.

3.2 Linear relationships between physical and chemical properties of soil and DDR (MLR model results)

The characteristics influencing DDR in the study area were determined with the linear method (i.e., the MLR); the results are depicted in Figure 4. Based on the obtained results, the effective parameters of DDR in the study area using the MLR method in autumn, winter, spring and summer were SAR (Fig. 4a), pH (Fig. 4b), clay (Fig. 4c) and gravel (Fig. 4d), respectively. Moreover, the parameter influencing annual DDR in the study area was SAR (Fig. 4e).

\subsection{Non-linear relationships between physical and chemical properties of soil and DDR (CHAID algo- rithm results)}

Figure 5 presents the characteristics influencing DDR in the study area, which were determined by using the non-linear decision tree CHAID method. Determinant parameters in autumn in order of importance coefficients (IC) were organic matter (IC $=0.34)$, sand $(\mathrm{IC}=0.28)$, silt $(\mathrm{IC}=0.25)$, and gravel $(\mathrm{IC}=0.14)$ (Fig. 5a), whereas the most effective parameters in winter were gypsum $(\mathrm{IC}=0.42$ ), sand $(\mathrm{IC}=0.38)$, clay $(\mathrm{IC}=0.14)$, and soil organic matter $(\mathrm{IC}=0.06)$ (Fig. 5b).

In spring, soil texture was introduced as a determinant parameter influencing the DDR within the area where sand content was the most important feature ( $\mathrm{IC}=0.39$ ) and silt percentage ( $\mathrm{IC}=0.26$ ) had the minimal effect (Fig. 5c). Prevailing westerly wind in spring (Fig. 2) and sand dunes in the west of the study region, which could lead to release of sand in the area, might be the most important factors explaining the importance of sand content. In summer, five variables including silt, sand, organic matter, gypsum and soil $\mathrm{pH}$ had a greater influence on DDR in the study area. Among these parameters, silt had the highest importance coefficient ( $\mathrm{IC}=0.31$ ), whereas $\mathrm{pH}$ and gypsum had the lowest IC (0.15) (Fig. 5d). Determinant parameters influencing annual DDR in the study area were sand, soil organic matter, silt, $\mathrm{CCE}$, clay and $\mathrm{pH}$, being sand the most important feature $(\mathrm{IC}=0.23)$ and $\mathrm{pH}(\mathrm{IC}=0.04)$ the least significant (Fig. 5e).

\subsection{Comparing MLR and CHAID model results}

Based on the results obtained from the MLR model, only one parameter was introduced as determinant factor affecting DDR in the study area. However, several parameters were determined as affecting 

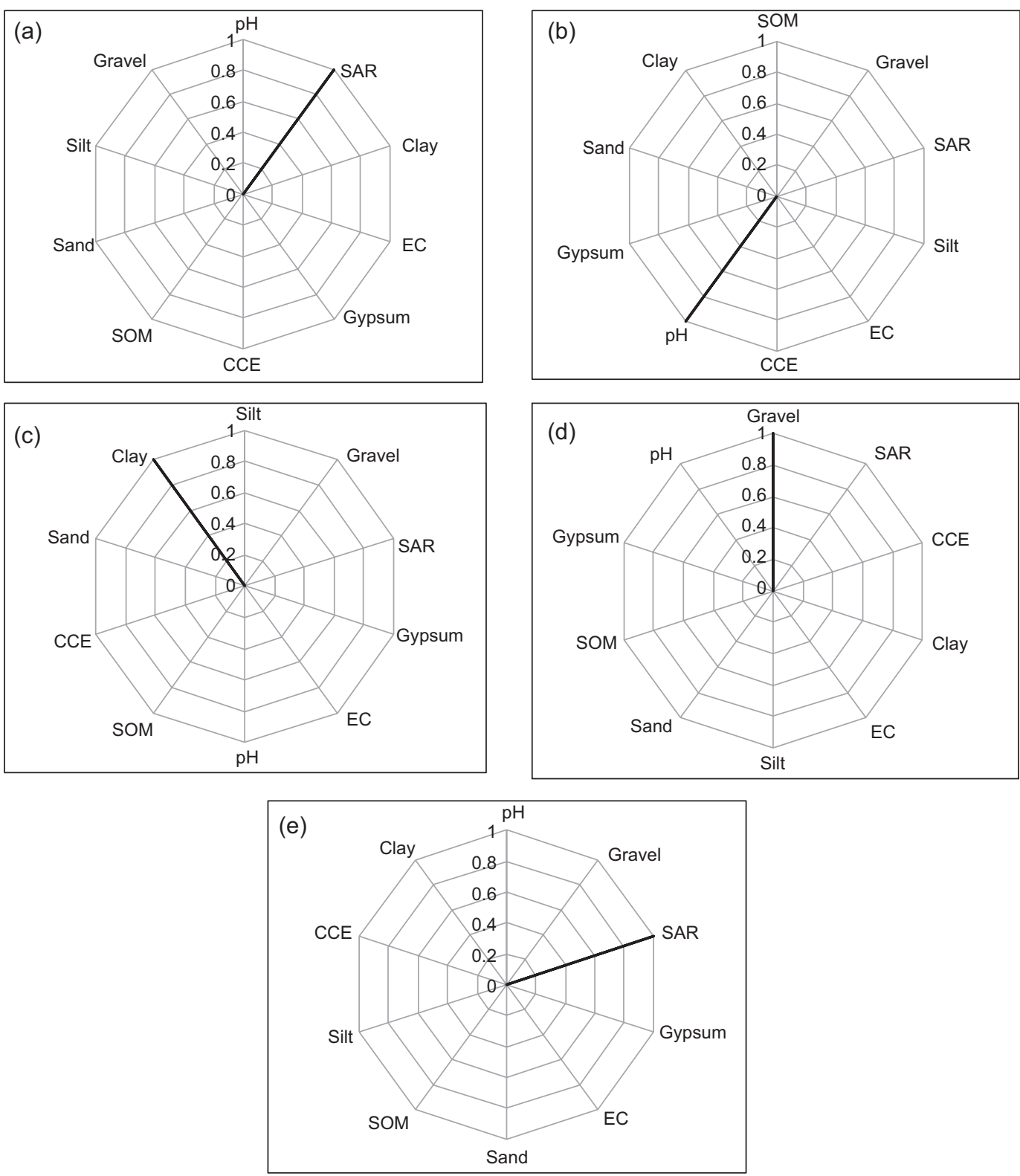

Fig. 4. Importance coefficient (IC) values of surface soil physical and chemical parameters in the Gavkhouni sub-basin affecting DDR in (a) autumn, (b) winter, (c) spring, and (d) summer, as well as (e) annual DDR using the MLR method.

factors in each sampling period with the non-linear CHAID algorithm method. In addition, according to the results obtained with the CHAID analysis, it appears that among the measured parameters, surface soil sand content in the Gavkhouni wetland had the greatest impact on DDR during the sampling periods, where similar particle size distribution of surface soil and atmospheric dust were found (see Table III).
Therefore, it can be concluded that the accuracy of MLR is unacceptable as compared with the non-linear CHAID algorithm to determine parameters influencing DDR in the Gavkhounisub-basin. Since the results of CHAID algorithm are more acceptable and much more similar to ground measurements and natural conditions of the study area, most soil physical and chemical properties seem to have non-linear 

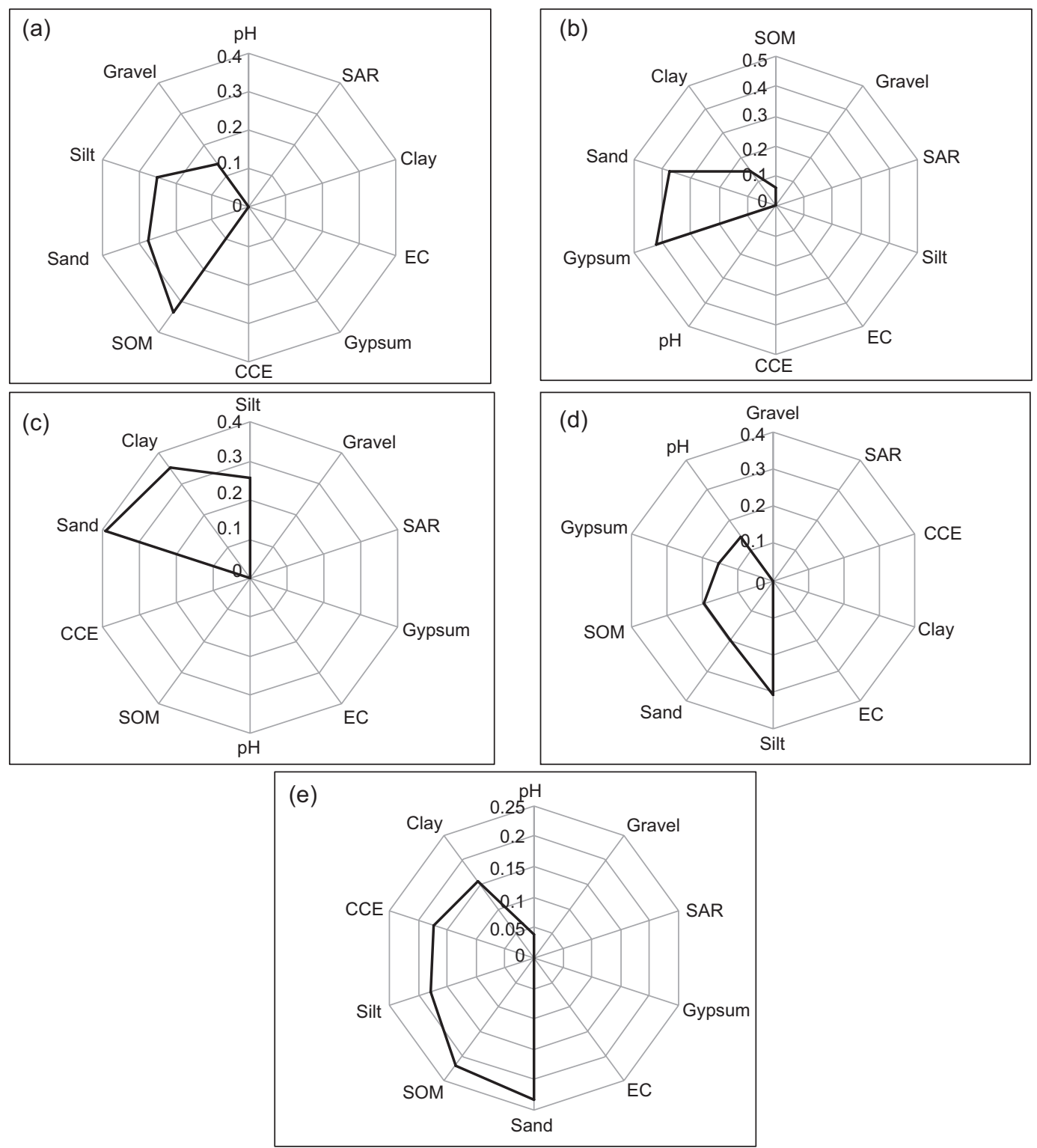

Fig. 5. Importance coefficient (IC) values of surface soil physical and chemical parameters in the Gavkhouni sub-basin affecting DDR in (a) autumn, (b) winter, (c) spring, and (d) summer, as well as (e) annual DDR using the CHAID method.

Table III. Particle size distribution of atmospheric dust and surface soil in the study area.

\begin{tabular}{lcccc}
\hline Sample & $\begin{array}{c}\text { Sampling } \\
\text { period }\end{array}$ & $\begin{array}{c}\text { Sand } \\
(\%)\end{array}$ & $\begin{array}{c}\text { Silt } \\
(\%)\end{array}$ & $\begin{array}{c}\text { Clay } \\
(\%)\end{array}$ \\
\hline Dust & Spring & 42.30 & 33.15 & 24.55 \\
& Summer & 49.73 & 29.13 & 21.14 \\
& Autumn & 56.16 & 26.27 & 17.57 \\
& Winter & 42.55 & 34.96 & 22.49 \\
Soil & Annual & 47.69 & 30.88 & 21.44 \\
\hline
\end{tabular}


relationships with DDR in the study area. Abbaszadeh Afshar et al. (2016) found that the CHAID algorithm had a greater ability to determine clay content with higher accuracy by comparing it with the MLR method for estimating clay. Besalatpour et al. (2015) used the MLR method to model aggregate stability and reported its non-acceptable accuracy for estimating and modeling the aggregate geometric mean diameter in the northern Karun Basin. Tóth et al. (2012) developed some transitional relations based on the CHAID classification tree and used them as input data; they concluded that classification tree methods (regression trees and CHAID) are useful and effective to model complex relationships between soil water retention and soil properties in salt affected soils. In general, the CHAID algorithm has extreme flexibility and high performance to detect complex nonlinear relationships between input and output data. On the other hand, training based methods in comparison with regression-based models have much more ability to recognize relationships between inputs and target variables. Therefore, it seems that in areas with high ecological complexity and complex nonlinear relationships among input and output data, nonlinear methods such as the CHAID algorithm are superior to linear methods such as MLR.

\section{Conclusions}

Atmospheric dust samples $(\mathrm{n}=124)$ were collected during four seasons from 31 sampling sites in the Gavkhouni wetland sub-basin, located in Central Iran, to investigate the surface soil physical and chemical properties which affect the seasonal and annual DDR using CHAID and MLR. According to the results obtained by the CHAID analysis, it appears that sand content has the highest impact on DDR in the study area among the surface soil parameters measured. The similarity of atmospheric dust particle size distribution and that of surface soil of the study area also confirms this finding. In this study, the MLR model did not have acceptable accuracy to determine the parameters affecting DDR in Gavkhouni wetland sub-basin in comparison with the non-linear CHAID algorithm. In fact, the results of CHAID were more acceptable and much more similar to measured data and natural conditions of the study area than MLR model. Therefore, it is concluded that soil physical and chemical properties have mostly non-linear relationships with DDR in the study area. These results can motivate researchers to use decision tree algorithms, particularly the CHAID method, as a novel method with relatively good accuracy and efficiency for determining nonlinear relationships of various properties with different soil characteristics, in order to achieve the greatest accuracy with minimal cost and time. However, further studies on factors affecting DDR in different regions under various weather conditions using a variety of decision tree algorithms are suggested to be carried out.

\section{References}

Abbaszadeh Afshar F., Ayoubi Sh., Besalatpour A.A., Khademi H. and Castrignano A., 2016. Integrating auxiliary data and geophysical techniques for the estimation of soil clay content using CHAID algorithm. J. Appl. Geophys. 126, 87-97.

DOI: $10.1016 /$ j.jappgeo.2016.01.015

Abuduwaili J., Liu D. and G. Wu, 2010. Saline dust storms and their ecological impacts in arid regions. J. Arid Land 2, 144-50.

DOI: $10.3724 /$ SP.J.1227.2010.00144

Al-Harbi M., 2015. Characteristics and composition of the falling dust in urban environment. Int. J. Environ. Sci. Technol. 12, 641-652.

DOI: $10.1007 / \mathrm{s} 13762-013-0440-8$

Allison L.E. and Moodie C.D., 1965. Carbonates. In: Methods of Soil Analysis (Black C.A., Evans D.D., Ensminger L.E., White J.L. and Clark F.C., Eds.). Madison, Wisconsin, USA: American Society of Agronomy, 1379- 1396.

Arimoto R., Webb J.L. and Conley T.M., 2005. Radioactive contamination of atmospheric dust over southeastern New Mexico. Atmos. Environ. 39, 4745-4754.

DOI: $10.1016 /$ j.atmosenv.2005.04.022

Artieda O., Herrero J. and Drohan P.J., 2006. Refinement of the differential water loss method for gypsum determination in soils. Soil Sci. Soc. Am. J. 70, 1932-1935. DOI: $10.2136 /$ sssaj2006.0043N

Besalatpour A.A., Hajabbasi M.A., Ayoubi S., Mosaddeghi M.R. and Schulin R., 2013. Estimating wet soil aggregate stability from easily available data in a highly mountainous watershed. Catena 111, 72-79. DOI: 10.1016/j.catena.2013.07.001 
Besalatpour A.A., Ayoubi S., Hajabbasi M.A., Gharipour A. and Yousefian Jazi A., 2014. Feature selection using parallel genetic algorithm for the prediction of geometric mean diameter of soil aggregates by machine learning methods. Arid Land Res. Manag. 28, 383-394. DOI: $10.1080 / 15324982.2013 .871599$

Besalatpour A.A., Shirani H. and Esfandiarpour Borujeni I., 2015. Modeling of soil aggregate stability using support vector machines and multiple linear regression. J. Water Soil 29, 406-417 (in Persian).

Burt R., 2004. Soil survey laboratory methods manual. Soil survey investigations report. Report No. 42. United States Department of Agriculture-Natural Resources Conservation Service, 736 pp.

Chapman H.D., 1965. Total exchangeable bases. In: Methods of soil analysis. Part 2. Chemical and microbiological properties (Norman A.G., Ed.). Agronomy Monograph 9.2. American Society of Agronomy, 902904. DOI: 10.2134/agronmonogr9.2.c7

Chattamvelli R., 2011. Data mining algorithms. Alpha Science, $400 \mathrm{pp}$.

Gee G.W. and Bauder J.W., 1986. Particle size analysis. In: Methods of soil analysis. Part 1. Physical and mineralogical methods (Klute A., Ed.). Agronomy Monograph 9. 2nd ed. American Society of Agronomy, 383-411. DOI: 10.12691/env-3-5-3

Gill T.E., 1996. Eolian sediments generated by anthropogenic disturbance of playas: human impacts on the geomorphic system and geomorphic impacts on the human system. Geomorphology 17, 207-28.

DOI: 10.1016/0169-555X(95)00104-D

Hojati S., Khademi H., Faz Cano A. and Landi A., 2012. Characteristics of dust deposited along a transect between central Iran and the Zagros Mountains. Catena 88, 27-36. DOI: 10.1016/j.catena.2011.09.002

Huang Y., Lan Y., Thomson S.J., Fang A., Hoffmann W.C., and Lacey R.E., 2010. Development of soft computing and applications in agricultural and biological engineering. Comp. Elect. Agr. 71, 107-127.

DOI: $10.1016 /$ j.compag.2010.01.001

Javed W., A Wexler.S., Murtaza G., Ahmad H.R. and Basra M.A., 2015. Spatial, temporal and size distribution of particulate matter and its chemical constituents in Faisalabad, Pakistan. Atmósfera 28, 99-116.

DOI: 10.20937/ATM.2015.28.02.03

Jickells T.D., An Z.S., Andersen K.K., Baker A.R., Bergametti G., Brooks N., Cao J.J., Boyd P.W., Duce R.A., Hunter K.A., Kawahata H., Kubilay N., Laroche J.,
Liss P.S., Mahowarld N., Prospero J.M., Ridgwell A.J., Tegen I. and Torres R., 2005. Global iron connection between desert dust, ocean biogeochemistry and climate. Science 308, 67-71.

DOI: $10.1126 /$ science. 1105959

Kass G.V., 1980. An exploratory technique for investigating large quantities of categorical data. Appl. Stat. 29, 119-127. DOI: $10.2307 / 2986296$

Kutiel H. and Furman H., 2003. Dust storms in the Middle East: Sources of origin and their temporal characteristics. Indoor Built Environ. 12, 419-426.

DOI: $10.1177 / 1420326 \times 03037110$

Lawrence C.R. and Neff J.C., 2009. The contemporary physical and chemical flux of Aeolian dust: A synthesis of direct measurements of dust deposition. Chem. Geol. 267: 46-63. DOI: 10.1016/j.chemgeo.2009.02.005

Liu D., Abuduwaili J., Lei J. and Wu G., 2011. Deposition rate and chemical composition of the Aeolian dust from a bare saline playa, Ebinur Lake, Xinjiang, China. Water Air Soil Pollut. 218, 175-84.

DOI: $10.1007 / \mathrm{s} 11270-010-0633-4$

Lu S.G., Bai S.Q. and Xue Q.F., 2007. Magnetic properties as indicators of heavy metals pollution in urbuntopsoils: A case study from the city of Luoyang, China. Geophys. J. Int. 171, 568-580.

DOI: 10.1111/j.1365-246X.2007.03545.x

Magidson J., 1993. The use of the new ordinal algorithm in CHAID to target profitable segments. J. Database Mark.1, 29-48.

Maroco J., Silva D., Rodrigues A., Guerreiro M., Santana I. and de Mendon A., 2011. Data mining methods in the prediction of dementia, a real-data comparison of the accuracy, sensitivity and specificity of linear discriminant analysis, logistic regression, neural networks, support vector machines, classification trees and random forests. BMC Res. Notes 4, 1-14.

DOI: $10.1186 / 1756-0500-4-299$

Massey F.J., 1951. The Kolmogorov-Smirnov test of goodness of fit. J. Am. Stat. Assoc. 4, 70-71.

DOI: $10.1080 / 01621459.1951 .10500769$

McTainsh G.H., Nickling W.G. and Lynch A.W., 1997. Dust deposition and particle size in Mali, West Africa. Catena 29, 307-322.

DOI: $10.1016 / \mathrm{S} 0341-8162(96) 00075-6$

McTainsh G.H., 1999. Dust transport and deposition. In: Aeolian environments, sediments and landforms (Goudie A., Livingstone S. and Stokes I., Eds.). Wiley, Chichester, 181-211. 
Menéndez I., Díaz-Hernández J.L., Mangas J., Alonso I. and Sánchez-Soto P.J., 2007. Airborne dust accumulation and soil development in the north-east sector of Gran Canaria (Canary Islands, Spain). J. Arid Environ. 71, 57-81.

DOI: $10.1016 /$ j.jaridenv.2007.03.011

Mousavifard S.M., Momtaz H., Sepehr E., Davatgar N. and Rasouli Sadaghiani M.H., 2013. Determining and mapping some soil physico-chemical properties using geostatistical and GIS techniques in the Naqade region, Iran. Arch. Agron. Soil Sci. 59, 1573-1589. DOI: $10.1080 / 03650340.2012 .740556$

Mu G., Yan S., Jilil A., He Q. and Xai X., 2002. Wind erosion at the dry-up bottom of Aiby Lake. Sci. China Ser. D Earth Sci. 45, 157-64.

DOI: $10.1007 / \mathrm{BF} 02878403$

Naderizadeh Z., Khademi H. and Ayoubi Sh., 2016. Biomonitoring of atmospheric heavy metals pollution using dust deposited on date palm leaves in southwestern Iran. Atmósfera 29, 141-155.

DOI: 10.20937/ATM.2016.29.02.04

Nielsen D.R. and Wendroth O., 2003. Spatial and temporal statistics - Sampling field soils and their vegetation. Catena Verlag, Reiskirchen, Germany, 398 pp.

Norouzi S., Khademi H., Faz Cano A. and Acosta J.A., 2015. Using plane tree leaves for biomonitoring of dust borne heavy metals: A case study from Isfahan, Central Iran. Ecol. Indic. 57, 64-73.

DOI: 10.1016/j.ecolind.2015.04.011

Norouzi S., 2016. Spatio-temporal variability of dust characteristics in Isfahan region and the possibility of using plane tree leaves for biomonitoring its contamination level. $\mathrm{PhD}$ thesis. Isfahan University of Technology (in Persian).

Page A.L., Miller R.H. and Keeney D.R. (Eds.), 1986. Methods of soil analysis. Part 2. Chemical and microbial properties. Agronomy Monograph 9. American Society of Agronomy, 363-364.

DOI: $10.1002 /$ jpln. 19851480319

Rajot J.L., 2001. Wind blown sediment mass budget of Sahelian village land units in Niger. Bull. Soc. Géol. France 172, 523-531.

DOI: $10.2113 / 172.5 .523$

Rashki A., Eriksson P.G., Rautenbach C.J. de W., Kaskaoutis D.G., Grote W. and Dykstra J., 2013. Assessment of chemical and mineralogical characteristics of airbone dust in the Sisten region, Iran. Chemosphere 90, $227-$ 236. DOI: 10.1016/j.chemosphere.2012.06.059
Schneider A., Hommel G. and Blettner M., 2010. Linear regression analysis. Dtsch. Arztebl. Int. 107, 776-782. DOI: $10.3238 /$ arztebl.2010.0776

Sing D. and Sing C.F., 2010. Impact of direct soil exposures from airborne dust and geophagy on human health. Int. J. Environ. Res. Public Health 7, 12051223. DOI: 10.3390/ijerph7031205

Small I., van der Meer J. and Upshur R., 2001. Acting on an environmental health disaster: The case of the Aral Sea. Environ. Health Perspect. 109, 547-549.

DOI: $10.2307 / 3455025$

Ta W., Xiao H., Qu J., Xiao Z., Yang G., Wang T. and Zhang X., 2004. Measurements of dust deposition in Gansu Province, China, 1986-2000. Geomorphology 57, 41-51.

DOI: $10.1016 / \mathrm{S} 0169-555 \mathrm{X}(03) 00082-5$

Tanaka T.Y. and Chiba M., 2006. A numerical study of the contribution of dust source regions to the global dust budget. Glob. Planet. Change 52, 88-104.

DOI: 10.1016/j.gloplacha.2006.02.002

Tesfahunegn G.B., Tamene L. and Vlek P.L.G., 2011. Catchment-scale spatial variability of soil properties and implications on site-specific soil management in northern Ethiopia. Soil Till. Res. 117, 124-139.

DOI: 10.1016/j.still.2011.09.005

Tóth B., Makó A., Guadagnini A. and Tóth G., 2012. Water retention of salt-affected soils: quantitative estimation using soil survey information. Arid Land Res. Manag. 26, 103-121.

DOI: $10.1080 / 15324982.2012 .657025$

Twarakavi N.K.C., Simunek J. and Schaap M.G., 2009. Development of pedotransfer functions for estimation of soil hydraulic parameters using support vector machine. Soil Sci. Soc. Am. J. 73, 1443-1452.

DOI: $10.2136 /$ sssaj2008.0021

Walkley A. and Black I.A., 1934. An examination of the Degtjareff method for determining soil organic matter and a proposed modification of the chromic acidtitration method. Soil Sci. 37, 29-38

Wang W.C., Chau K.W., Cheng C.T. and Qiu L., 2009. A comparison of performance of several artificial intelligence methods for forecasting monthly discharge time series. J. Hydrol. 374, 294-306.

DOI: $10.1016 /$ j.jhydrol.2009.06.019

Xuan J., Sokolik I.N., Hao J., Guo F., Mao H. and Yang G., 2004. Identification and characterization of sources of atmospheric mineral dust in East Asia. Atmos. Environ. 38, 6239-6252. DOI: 10.1016/j.atmosenv.2004.06.042 
Zarasvandi A., Carranza E.J.M., Moore F. and Rastmanesh F., 2011. Spatio-temporal occurrences and mineralogical-geochemical characteristics of airborne dusts in Khuzestan Province (southwestern Iran). J. Geochem. Explor. 111, 138-151. DOI: 10.1016/j.gexplo.2011.04.004
Zheng N., Liu J., Wang Q. and Liang Z., 2010. Health risk assessment of heavy metal exposure to street dust in the zinc-smelting district, northeast of China. Sci. Total Environ. 408, 726-733.

DOI: $10.1016 /$ j.scitotenv.2009.10.075 